\title{
Curator's Independence in Bankruptcy Court Case
}

\author{
Sudjanto Sudiana ${ }^{1}$, Suparno ${ }^{2}$ \\ Student Program Doctor of Law Borobudur University, Jl. Pemuda, RT.1/RW.3, \\ Rawamangun, Kec. Pulo Gadung, DKI Jakarta 13220, Indonesia ${ }^{1,2}$ \\ \{Sudiana_sudjanto@yahoo.com¹,suparno@borobudur.ac.id $\left.{ }^{2}\right\}$
}

\begin{abstract}
In principle, bankruptcy falls into the category of civil law, but it can also enter the criminal law realm in some cases. When the bankruptcy curator is responsible for the management and eradication of bankrupt property becomes a criminal defendant. This research uses normative legal analysis, where legal research is used to find the rule of law, legal principles and legal doctrines to answer legal problems faced. This study's result is that curators can be criminally indicted when proven to be independent in bankruptcy trials.
\end{abstract}

Keywords: Bankruptcy; Curatorial Independence; Criminal law

\section{Introduction}

The matter of bankruptcy is part of civil law or, more specifically, included in the scope of trade law, so this law should not touch the criminal law issue. However, bankruptcy cases eventually developed into criminal matters, namely when the bankruptcy curator responsible for managing and eradicating bankrupt property was seated as a defendant in a criminal case on charges of committing a criminal offence. In this regard, it can be concluded that criminal law is a law aimed at and applied to any person or anyone who commits a criminal act without discrimination. There are in contrast to the inclusion of criminal sanctions in Law No. 37 of 2004, which is only addressed to curators who prove not independent. The results showed criminal law everywhere, including bankruptcy law, was not free from criminal law.1 These facts eventually developed and resulted in resolving the settlement of bankruptcy assets that should be turned into complicated.

The settlement of bankruptcy property's complexity is further increased by including the criminal sanctions article in the Bankruptcy Law, which states that if proven curators are not independent, they can be subject to legal sanctions, both criminal and civil legislation. One of the threats of criminal sanctions against the curator is the curator's disrespectful attitude. It becomes a new problem, especially related to criminal liability, namely determining standards that the curator is not independent and deserves to be punished - sanctions contained in the Bankruptcy Act.

\section{Methods}

This research is a normative legal analysis using standard research methods to find the rule of law, legal principles, and legal doctrines to answer legal problems. By conducting 4 (four) 
approaches, namely: 1) statute approach by studying all laws and regulations related to legal issues discussed in the study, 2) Conceptual approach by reviewing the concept of bankruptcy, the idea of independence, the notion of abuse of authority, the notion of criminal liability, and the concept of justice. 3) The case approach was chosen because dogmatically, the bankruptcy law has governed the parties' duties and functions in bankruptcy. This case approach is also reviewed court rulings that have to do with research that contains a connection between bankruptcy law and criminal law. The research on this Court's decisions can be known as ratio decidendi, which is the basis of consideration of the judge in deciding the case. Ratio decidendi shows that the science of law is prescriptive, not descriptive. The prescription given will determine the value of this study. 4) Legal comparison approach, used to find answers to some unanswered questions with bankruptcy law approach. As for comparing this law, the chosen country is the Netherlands because it has a very close relationship with the State of Indonesia, namely since the colonial period. Even with many Dutch laws that Indonesia still uses from the beginning of independence, national law development is still heavily influenced by Dutch laws.

\section{Discussion}

The principle of independence and impartiality is one of the central tenets known in various international law provisions. The Bankruptcy Law also requires a declaration of independence. It is expressly stated in Article 15 paragraph (3) of the Bankruptcy Law that the curator appointed in paragraph (1) must be independent, have no conflict of interest with the debtor or creditor, and not currently handling bankruptcy. Cases and late payment of debts in more than three instances. The article's sound is the same as Article 234 paragraph (1), i. e. the appointed administrator, referred to in Article 225 paragraph (2), must be independent and have no conflict of interest debtor-creditor. The similarity of the intent of Article 15 paragraph (3) and Article 234 data (1) of the Bankruptcy Law describes. However, the Bankruptcy Law distinguishes the scope of duties and authorities between curators and administrators. Still, it does not offend the legal position, including in what cases curators or administrators can be subject to criminal responsibility. The provisions regarding the principle of independence are affirmed in the Code of Ethics for the Indonesian Curators and Administrators Association (AKPI), which states that Indonesian Curators and Administrators Association members must be in every curator independent appointment and free from any influence.

From these two understandings, it is concluded that independent means that curators should not depend on the parties in bankruptcy, namely debtors or curators, and free from anyone's influence. Associated with Bryan A. Gardner in Black's Law Dictionary, the Independent is not subject to the control or influence of another, not associated with another, not dependent contingent on something else (an independent person). At the same time, a curator is a person who manages the affairs of another, a guardian.

The Official Minutes of Discussion of the Draft Law on Bankruptcy and Suspension of Debt Payment Obligations from the House of Representatives mentioned that the curator should be an independent party, which does not have any conflict of interest either with the debtor or creditors. Because the curator in the provisions of Article 15 paragraph (3) of Law Number 37 the Year 2004 is the party authorized to manage bankruptcy assets since the bankruptcy decision so that the curator is obliged to take actions that do not benefit one not harm the other party. 
The description of independence above, the meaning of autonomy in bankruptcy, is related to the curator's inner attitude, which upholds honesty, freedom, neutral attitude or equitable interests of either the debtor or creditor. Implementing its duties must also support the values of integrity and objectives to eradicate bankrupt assets reasonably for both creditors and debtors. There are important because, in managing and eliminating bankrupt property, curators are often faced with difficult situations between debtors and creditors' interests. Even many temptations for the curator's economic interests in question end harm the bankrupt property.

Furthermore, Article 15 paragraph (3) of the Bankruptcy Law is connected with Article 234 paragraph (2) and the Criminal Law theory. It becomes unclear about the criteria of independent acts that can result in a curator being sentenced. Because the criminal law has a strict limit to impose a crime against a person that is fulfilled 3 (three) pillars in criminal law, the first is the element of criminal acts. The second is the existence of criminal offences and liability, and the third is about criminal sanctions. In contrast, the two articles in the Bankruptcy Law above do not explain the elements of deeds included as acts that are not independent. The research found that this independent use refers more to professional standards that must be upheld and not an element of a criminal act.

\subsection{The Principle of Independence for Curators in Bankruptcy Law as a Moral Standard}

As a professional standard, the existence of independent values serves to prevent curators from being subjected to criminal sanctions. Therefore, before discussing bankruptcy curators' accountability, it is necessary first to understand and equate the curator's position as a legal profession. There are 3 (three) things that underlie a profession, namely:

a. Based on knowledge and not based on common sense. That is, a profession is obtained

from the process of learning science on an ongoing basis.

b. Having a skill is not just knowing, but talent must support that knowledge.

c. Bound by a moral standard, this is closely related to ethical values.

$\mathrm{K}$. Bertens stated that morals also need the law because morals are only financial if they are not disclosed and institutionalized in society. Just as in criminal law, prohibitions not to kill, not to cheat, not only prohibitions. Morals, but the act is also prohibited by law. The person who does it must also be punished firmly. The law also sets out the consequences in more detail of moral principles.

The principle of independence is also part of a moral standard, which the curator's profession must uphold, ensuring the preservation of moral values closely related to ethical reasons. Therefore, if there is a violation of ethics in the future, it is necessary to review whether the offence is identical to the law's breach. Because the law is the norm, while morals are not necessarily the norm of the law, the law's violations may be subject to legal sanctions. Still, violations of ethics are not necessarily subject to legal sanctions.

The thing that needs to be created is a shared perception regarding the values of independence. In the Bankruptcy Law itself, interpretation is ambiguous, so it is necessary to formulate performance indicators for curators, which can be used as guidelines for curators in carrying out their duties. To measure a curator's error to be sentenced to a criminal sanction, he must pay attention to his actions' ethical values. So if there is a violation of ethics, it is proven that the curator has committed a criminal act. However, on the other hand, some ethics remains the realm of ethics, with the wrong benchmark, is not to return it to moral standards and ethical standards. This ethical violation is known as unprofessional conduct.

Black's Law Dictionary is independently defined as not subject to another's control or influence, not dependent or contingent on something else (an independent person). It is also 
associated with objective ethics based on externally verifiable phenomena instead of an individual's perceptions, feelings, or intentions, without bias or prejudice. Based on that, independence is closely related to ethical issues. When ethics itself is closely related to absolute moral matters, then the view that one's actions can be seen as clearly right or wrong, regardless of the situation or consequences, are ethically objective absolutism.

Based on the above exposure, independence in bankruptcy law may mean that the curator must not and cannot be intervened by any kind either by the debtor, creditor, or other individuals within the bankruptcy institution or outside the bankruptcy institution. A curator must have an attitude of integrity that contains values such as noble morals, trust in carrying out his position, being wise and prudent in facing the multiple realities between debtors and creditors' interests, consistent between words and responsibilities that he carries, obeying good values and norms. Written or unwritten and no less critical, always oriented to the best interests of the bankruptcy estate. A curator who expresses his willingness to accept the duties and responsibilities of managing a bankrupt debtor's property based on a commercial court ruling must ensure himself free from conflicts of interest from both the debtor and the creditor. The curator also must respect every right of the relevant party in connection with the legal action he committed against the bankrupt property. No less important is that the curator must keep his behaviour from committing a despicable act, taking advantage of the bankrupt property unlawfully.

Furthermore, independence is also closely related to the objective values that curators should uphold. The curator's position will always stand between 2 (two) legal interests, namely the legal interests of debtors and the legal claims of creditors. Therefore, curators are obliged to maintain the trust that the Court, debtors and creditors have given, uphold truth and justice and adhere to professional and ethical standards following the content and spirit that underlies it, as well as maintain professional relationships that govern working relationships with related parties, namely debtors, creditors and Supervisory Judges. Also, objectivity is reflected in curators' attitude who can act fairly, impartially, and not prejudiced or biased. Curators must be free from the interests or influences of others.

Based on the description above, curators are a legal profession. As a profession, curators are bound by the code of ethics of the curator profession. Indonesia is currently known for several professional organizations of curators, among others the Association of Curators and Administrators of Indonesia (AKPI) and the Association of Indonesian Curators and Administrators (KPI). From the code of ethics of the profession, if there is a violation in the implementation of duties and responsibilities of the work, it can be distinguished into 2 (two) things, namely: first unprofessional conduct and second, administrative mall, where unprofessional conduct is closely related to the capabilities or capabilities of the curator concerned, while the administrative mall is related to the despicable behaviour of the curator.

Based on the above exposure, independence in bankruptcy law may mean that the curator must not and cannot be intervened by any kind either by the debtor, creditor, or other individuals within the bankruptcy institution or outside the bankruptcy institution. Independence reflects a curator's integrity who glorifies values such as noble morals, trustworthiness in carrying out his work, and wise in dealing with multiple realities between debtors and creditors' interests, consistent between speech and responsibilities obedience to values and norms both written and unwritten. And critical of common interests. Besides, a curator who expresses his willingness to accept the duties and responsibilities of managing a bankrupt debtor's property based on a commercial court ruling must also ensure himself free from conflicts of interest from both the debtor and the creditor. The curator should also respect every right of the relevant party connected with the legal action he committed against the 
bankrupt property. No less important is that the curator must keep his behaviour from committing a despicable act, taking advantage of the bankrupt property unlawfully.

Furthermore, independence is also closely related to the objective values that curators should uphold. The curator's position will always stand between 2 (two) legal interests, namely the legal interests of debtors and the legal claims of creditors. Therefore, curators are obliged to maintain the trust that the Court, debtors and creditors have given, uphold truth and justice and adhere to professional and ethical standards under the content and spirit that underlies it, as well as maintain professional relationships that govern working relationships with related parties, namely debtors, creditors and Supervisory Judges. Besides, objectivity is also reflected in curators' attitude, who can act reasonably, impartially, and not prejudiced or biased. Curators must be free from the interests or influences of others.

Based on the description above, curators are a legal profession. As a profession, curators are bound by the code of ethics of the curator profession. Indonesia is currently known for several professional organizations of curators, among others the Association of Curators and Administrators of Indonesia (AKPI) and the Association of Indonesian Curators and Administrators (HKPI). From the code of ethics of the profession, if there is a violation in the implementation of duties and responsibilities of the work, it can be distinguished into 2 (two) things, namely: first unprofessional conduct and second, administrative mall, where unprofessional conduct is closely related to the capabilities or capabilities of the curator concerned, while the administrative mall is related to the despicable behaviour of the curator.

In connection with the violation of the code of conduct, the curator's organization is obliged to take action and sanction the curator. Sanctions can be in the form of reprimand, suspension, dismissal, even up to the revocation of permission by the Minister of Law and Human Rights (Menkumham) as the authorized agency to issue an authorization to appoint curators. This dismissal sanction is to prevent more significant losses in the future.

The above description then the role of criminal law concerning the curator's accountability should return to understanding criminal law's function. Wherefrom the results of the research conducted, Criminal Law has 2 (two) parts, namely: first, criminal law as autonomous or independent and second, criminal law as a guardian of norms. Criminal law as an autonomous law, then the criminal sanctions listed are primus remedium against the actions committed or, in other words, law enforcement prioritizes the criminal process. However, if the criminal law is a guardian of the norm, then the criminal law is as ultimum remedium or a last resort in a violation of the law.

Concerning curators as a legal profession, not all mistakes made by curators need to be punished. Because the function of criminal law in bankruptcy, as stated in the beginning, is a guardian of norms, it aims to prevent curators from committing despicable acts or unlawful acts. So its nature is ultimum remedium. However, criminal law can still be enforced as long as the curator meets the crime elements he allegedly committed according to criminal law.

From the description above, there needs to be a clear moral standard on the principles of independence related to curators' profession. There can be done by formulating and describing it in the curators' code of conduct and the Bankruptcy Law. On the one hand, a precise formulation of curators' independence can guide curators in carrying out their professional duties. On the other hand, it is also beneficial for law enforcement officers, especially judges, to formulate the correct independence values and determine criminal responsibility. The act committed fulfils the element of a criminal act. At the same time, there is the embodiment of law equality before the law,i.e. everyone has the same position before the law.

\subsection{Sanksi Pidana Berkaitan Dengan Kepailitan}


The curator is responsible for his/her mistakes or omissions in carrying out management duties or corrections that cause losses to insolvency assets. The term error or omission here should be given a clear and broad understanding. If not, it will undoubtedly cause problems for the curator in carrying out his duties, in the sense that he will not be able to take swift action because mistakes or omissions overshadow it. Therefore, it is necessary for a standardized assessment issued by an association. Also, it should be emphasized that the contemporary curator's responsibility may arise if, in the form of negligence or negligence, there should be an element of deliberateness or carelessness committed without explicit consideration.11 Also, the Bankruptcy Law also does not discuss what non-independent acts can cause a criminal conviction. The Bankruptcy Act only states criminal sanctions can be imposed when proven, not independent.

The inclusion of criminal sanctions in Article 234 paragraph (2) indicates that the Bankruptcy Law does not mess with curators' provisions must be independent. However, the Bankruptcy Law and its Explanation are also not consistent in the inclusion of these criminal sanctions, because there is no mention of the forms of sanctions that can be imposed on curators that prove not independent, as well as in the implementing regulations of the Bankruptcy Law also there is not a single provision that offends on this subject. Therefore, whether or not to impose criminal sanctions against curators who are not independent in general criminal sanctions imposed refers to the general provisions in the Criminal Code as outlined in the previous discussion, it becomes very excessive if the Bankruptcy Law which is the realm of civil affairs also regulates the issue of criminal sanctions. The reason required in the Bankruptcy Law is to determine the criteria of independence principle to be used as a guideline for curators in carrying out their duties, even for law enforcement officials (police, prosecutors and judges) in handling bankruptcy cases that intersect with the Criminal Law.

In the handling of bankruptcy cases today, bankruptcy cases end in mutual reporting and mutual dispute between debtors, creditors and curators. These kinds of things are the cause of the blunder of the law enforcement process in Indonesia. So one problem has not been solved already, ridden by another question. It is not uncommon for legal issues brought to the Court to produce out-of-sync rulings. They can happen because there is no common perspective among law enforcement officials in sitting an issue. So it is not wrong to think that law enforcement agencies are exploited by people who want to complicate law enforcement, which is further away from the principle of justice and legal certainty.

In terms of the inclusion of criminal sanctions, good law must first formulate a prohibition norm or order norm that states the act will be criminalized if violated. The model must explicitly mention the prohibited act by saying the article or several articles containing the standard. While the criminal sanctions in Article 234 paragraph (2) of the Bankruptcy Law only determine if proven not independent will be subject to criminal sanctions following the legislation. Noting that, it is also not explained the reference of the bill in question. Because the articles only mention the word 'not independent', while the benchmark of independence intended for criminal prosecution does not exist. Because, a law when it comes to other criminal provisions, including, in this case, the Criminal Code, there must be similar elements or elements of the norms referred too. In my opinion, independence is not an element of criminal acts, nor is it a legal norm that can be criminalized. Liberty is a value that becomes a moral standard that still has to be realized in a regular model.

Although there is a list of criminal sanctions in the Bankruptcy Law, the unregulated aspects of criminal law resulted in invalidating the principle of lex specialist derogates legislation generalist with the Criminal Code provisions. So in tackling criminal acts against 
the perpetrators of bankruptcy, the Criminal Code's general conditions are enforced. It is also to maintain the shortcomings that exist in Bankruptcy Law. Based on this, Article 234 paragraph (2) of the Bankruptcy Law provisions, as long as the phrase is sentenced to criminal sanctions, is a provision that has no meaning.

Criminal law dynamics are no less attractive from the above exposure than other legal variants such as constitutional law, international law, or humanitarian law. As for the substance of the debate in criminal law tends to be classical. There are none other than because it has always been associated with the principle of legality. As revealed by Dupont in Sapardjaja Het, legalities begin is een van de meest fundamental beginselen van het strafrecht. The focus of legitimacy is a very fundamental principle of criminal law.

The focus of criminal law arrangements relates to the problems of crimes that occur in the community. Criminal law serves as a guard so that the community avoids corruption. Suppose the Constitutional Court is often referred to as The Guardian of Constitution. The criminal law about the crime deserves to be referred to as The Guardian of Security which seeks to provide reassurance so that the public does not become victims of crime. Criminal law revolves around what acts are prohibited or required to citizens about actions that are categorized as criminal acts.

In its development, Criminal Law is no longer only limited to regulating matters related to crime but more broadly penetrated other areas of law such as administrative law, state and civil law. Criminal law is residual because criminal law is considered to provide benefits when constitutional law and civil law are considered no longer able to resolve the issue. After all, the sanctions in criminal law are torture, suffering, and suffering. While sanctions in the constitutional law, for example, in the form of dismissal from office. On the other hand, the maximum sanction in civil law is in the form of compensation. From this, it appears that the criminal law's punishment is much harsher than the civil law, among which is to eliminate the freedom and freedom of others who are sentenced to prison.

Delik formulation in criminal law and criminal procedural law occupies a significant place because if examined in earnest, offence formulation has 2 (two) functions, namely: the first, as we know related to the concrete application of the principle of legality, which means that criminal sanctions may only be applied to acts that were first determined as acts that can be criminalized by legislators (materially criminal law), or in other words, the legislator does this through offence formulation. The second, reviewed from the essential function of legality, is protecting from the law. Thus, offence formulation also has another part that is a function of evidence instruction (legally criminal events). Therefore, an offence formulation can indicate what things must be proven according to the law. Everything listed in the offence formulation (but not more than that) must still be established according to the rule of criminal procedural law.

Furthermore, to analyze curators' actions suspected of committing criminal acts, it is necessary first to understand the curator's duties and obligations and the criteria of such acts to qualify as criminal acts. Also, no less important is whether it contains the reason for justification or forgiveness of the deeds. Therefore, law enforcement is conducted against cases involving curators. It is necessary to be careful in determining management's action and or eradication of bankrupt property meets the category as a criminal act or only a violation of the code of ethics or a breach of civil law.

In connection with the above, the element of error is not included in the sense of criminal acts and is more appropriately an element of criminal liability. Nevertheless, criminal acts and criminal liability has a very close and fundamental relationship. With determining the 
misconduct of a curator resulting in criminal liability, a judge must first consider whether or not there is a reason to negate the criminal.

\section{Conclusion}

Ratio Legis imposed criminal sanctions for curators who are not independent aim: (a) Prevent curators from committing acts / criminal acts in the framework of implementing management duties and eradication. Here, criminal law's role is as a guardian of norms in the Bankruptcy Law related to curators' duties and responsibilities. This is the curator or administrator, before expressing his willingness to accept duties and responsibilities from the consequences of the decision of bankruptcy or delay of debt payment obligation (PKPU), really ensures that he does not commit a despicable act to take advantage of bankrupt property unlawfully, (b) As a preventive effort that prevents the occurrence of violations that can damage the joints of association in the community and aims to prevent parties in bankruptcy from committing acts, activities, actions, movements that are contrary to existing regulations in society. (c) Serve as social control is conducted when other efforts are inadequate, and ultimum remedium (the last drug) controls and maintains bankruptcy law norms.

Criminal liability curators who are not independent refers to the fulfilment of three pillars in criminal law. Namely, there are criminal acts, mistakes that result in criminal liability, and related criminal or criminalization based on the principle of independence, namely curators under challenging situations can take decisive action in the interests of bankrupt property. The ratio of decided judges in handing down the verdict against the curator does not directly refer to the curator's independence in Article 234 paragraph (2) of the Bankruptcy Law but instead refers to the Criminal Code.

\section{References}

[1] Agung Putu Wiwik S, Lis Julianti. 2020. "Penanggulangan Covis-19 Berbasis Desa Adat Dalam Perspektif Perlindungan Hukum Terhadp Aparatur Desa Adat.” Prosiding Seminar Nasional Webinar Nasional Universitas Mahasaraswati Denpasar "Percepatan Penanganan COVID-19 Berbasis Adat di Indonesia": 71-76.

[2] Agustino, Leo. 2020. "Analisis Kebijakan Penanganan Wabah Covid-19: Pengalaman Indonesia Analysis of Covid-19 Outbreak Handling Policy: The Experience of Indonesia." Junal Borneo Administrator 16(2): 253-70.

[3] Ariany, Farida, and Murtiana Ningsih. 2019. "Perlindungan Hukum Terhadap Identitas Pasien Covid 19." Journal of Chemical Information and Modeling 53(9): 1689-99.

[4] Mukhlis, Sihabudin. 2018. "Perlindungan Hukum Jemaah Umrah Dalam Penyelenggaraan Perjalanan Ibadah Umrah.” Asy-Syari'ah 20(1): 49-58.

[5] Muhammad, Ilyas, Bambang Winarno, and Rachmad Safa'at. 2020. "Jurnal Ilmiah Pendidikan Pancasila Dan Kewarganegaraan.” Jurnal Ilmiah Pendidikan Pancasila dan Kewarganegaraan 5(1): 131-38. http://journal2.um.ac.id/index.php/jppk/article/view/7820/3749.

[6] Nathasya Victoria Ruswandana*, Bambang Eko Turisno, Suharto. 2016. "Perlindungan Hukum Terhadap Konsumen Dalam Pembatalan Keberangkatan Ibadah Haji Khusus Oleh Biro Penyelenggara Ibadah Haji Khusus.” Diponegoro Law Review 5(3): 1-12. 
[7] Pesulima, Theresia Louize, and Yosia Hetharie. 2020. "Perlindungan Hukum Terhadap Keselamatan Kerja Bagi Tenaga Kesehatan Akibat Pandemi Covid-19.” Pesulima, Theresia Louize Hetharie, Yosia 26(2): 280.

[8] Suryani, Dewi Ervina. 2013. "Perlindungan Hukum Terhadap Penetapan Status Covid19 Pada Pasien Penyakit Umum Oleh Rumah Sakit Di Kota Medan.” Jurnal Hukum Kaidah 20(2): 127-35.

[9] Sholikin, M Nur, and Herawati. 2020. "(Legal Aspects of Occupational Safety and Health for Medical and Health Workers During the Pandemic)." Majalah Hukum nAsional 50(2): 1-20.

[10] Tuwu, Darmin. 2020. "Kebijakan Pemerintah Dalam Penanganan Pandemi Covid-19." Journal Publicuho 3(2): 267. 